\title{
Patient safety culture in critical and non-critical areas: a comparative study*
}

\section{Cultura de segurança do paciente em áreas críticas e não críticas: estudo comparativo Cultura de seguridad del paciente en áreas críticas y no críticas: estudio comparativo}

How to cite this article:

Carneiro AS, Dalmolin GL, Magnago TSBS, Moreira LP, Costa ED, Andolhe R. Patient safety culture in critical and non-critical areas: a comparative study. Rev Esc Enferm USP. 2021;55:e20210141. http://dx.doi.org/10.1590/1980-220X-REEUSP-2021-0141

\section{Alessandra Suptitz Carneiro' \\ Graziele de Lima Dalmolin ${ }^{1}$ \\ D Tânia Solange Bosi de Souza Magnago ${ }^{1}$

(D) Laura Prestes Moreira ${ }^{1}$
(iD) Eduarda Dalla Costa ${ }^{1}$
(i) Rafaela Andolhe ${ }^{1}$

* Extracted from the dissertation "Occupational stress, burnout and patient safety culture among hospital workers in semi-critical and critical areas", Universidade de Santa Maria, 2019.

${ }^{1}$ Universidade Federal de Santa Maria,

Departamento de Enfermagem,

Santa Maria, RS, Brazil.

\begin{abstract}
Objective: to compare the perception of patient safety culture among health workers from critical and non-critical areas. Method: cross-sectional study with health workers from critical and non-critical areas of a large hospital. Data collection used a characterization instrument and the Safety Attitudes Questionnaire. The analysis was performed in the Predictive Analytics Software Statistic ${ }^{\circledR}$. Results: a total of 393 workers participated, predominantly women, over 43 years old, nursing technicians, with a partner, and children. Results indicated that the areas have a negative perception of patient safety $(66.5 \%, \pm 12.7$ critical; $63.5 \%, \pm 14.4$ noncritical). Only job satisfaction had a positive score $(83.0 \%, \pm 15.9$ critical; $80.1 \%, \pm 17.5$ non-critical). There was a relationship between being a worker in critical areas and having a positive perception of the unit's management $(p=0.041)$. Conclusion: both areas have a negative perception of the safety culture. Although critical areas have obtained more positive evaluations, the results did not show statistical significance when compared to non-critical areas.
\end{abstract}

DESCRIPTORS

Nursing; Patient Safety; Hospitals; Hospital Units; Comparative Study. 


\section{INTRODUCTION}

The search for the quality of health services has gained prominence among the priorities of hospital organizations, aiming to potentiate actions aimed at patient safety and to qualify care. In this context, transforming the work environment into a safer environment implies acting from the perspective of a safety culture in health institutions. According to the Collegiate Board Resolution (RDC) No. 36, safety culture is the set of values, attitudes, skills, and behaviors determining the commitment to health and safety management, replacing guilt and punishment with the opportunity to learn from failures and improve health care ${ }^{(1)}$.

In the hospital environment, spreading the safety culture is essential for workers to feel involved and co-responsible for safe care. Although institutions have invested in changes and in the adoption of protocols, difficulties in adhering to these measures have still been observed in healthcare practice $^{(2-3)}$.

A narrative review study on patient safety culture in the hospital environment, carried out in the Theses and Dissertations Catalog of the Coordination for the Improvement of Higher Education Personnel in January 2020 , identified 23 studies on the subject. There was a predominance of theses with a quantitative approach, which used validated questionnaires, mainly with the nursing staff working in critical areas. The results showed that the patient safety culture is weakened ${ }^{(4)}$. Based on the foregoing, and knowing that in the hospital environment, critical and non-critical areas have differences that shall be considered (such as the work process, teamwork, standards, protocols, patient profiles), an important gap was found for the construction of knowledge in health, which warrants the relevance of a comparative study.

Thus, the question is: if the predominant safety culture is negative, is there a difference in the perception of patient safety culture in critical and non-critical areas in the hospital environment? Therefore, identifying particularities that may enhance or hinder safety in these areas can contribute to directing actions to strengthen the patient safety culture. We started from the hypothesis that there is a difference between the patient safety culture in critical and non-critical areas in the hospital environment. The objective was to compare the perception of patient safety culture among health workers from critical and non-critical areas.

\section{METHOD}

\section{Design of Study}

This is a cross-sectional study guided by the STROBE tool.

\section{Population}

All health workers from critical areas (Neonatal, Pediatric, and Adult Intensive Care Units; Cardiovascular Intensive Unit; Obstetric Center and General Surgery Area) and noncritical areas (Internal Medicine I and II, Admission at the General Surgery, Pediatric, and Toco-Gynecological Units) were included in the study. Health workers are understood as physicians, nurses, technicians (nursing, radiology, laboratory and pharmacy), physiotherapists, dentists, social workers, psychologists, speech therapists, pharmacists, and nutritionists.

\section{LOCAL}

Large public hospital, located in the central region of Rio Grande do Sul (RS). It should be noted that this institution is linked to the hospital network called Rede Sentinela and a public university. It is also a reference center for the region covered by the 4th State Health Coordination of RS, therefore providing highly complex care to referred patients.

\section{Selection Criteria}

The following inclusion criteria were adopted: being a worker at the institution, having worked at least four weeks in the department, with a minimum workload of 20 hours per week. This period was considered the minimum for the worker to be sufficiently exposed to the culture of the unit, allowing him/her to respond to the research adequately ${ }^{(5)}$. Workers away from work, for any reason, during the data collection period, were excluded.

\section{Sample Definition}

The population had 716 workers. Of these, 368 workers are from critical areas and 348 workers from non-critical areas. As this is a census, all workers in these areas were invited to participate in the survey, aiming to reach the minimum sample criterion ${ }^{(6)}$ as per the following calculation:

$$
\frac{\mathrm{n}=\mathrm{x}^{2} \cdot \mathrm{NP}(1-\mathrm{P})}{\mathrm{d}^{2}(\mathrm{~N}-1)+\mathrm{x}^{2} \cdot \mathrm{P}(1-\mathrm{P})}
$$

Where: $\mathrm{n}=$ sample size; $\mathrm{X}^{2}=$ chi-square value for 1 degree of freedom at the confidence level of 0.05 and equal to 3.89 (pre-determined fixed value); $\mathrm{N}=$ the population size; $\mathrm{P}=$ the proportion of the population the study wants to estimate (it is assumed to be 0.50 , as this proportion would provide the maximum sample size); $d=$ the degree of precision expressed as a proportion (0.05). Based on the calculation, a minimum sample of 322 participants was estimated.

\section{Data Collection}

The investigation used a database from the matrix project "Patient safety culture and health problems for workers in a hospital environment", with authorization from the researcher in charge. This project is a cross-sectional investigation, whose objective was to assess the patient safety culture and the health problems of workers in a hospital environment, carried out through a census with all workers (health and support professionals) of a public hospital in Rio Grande do Sul. Data were collected from March to August 2018, a period in which workers were invited at their workplace to participate in the study. It should be noted that, after accepting to participate in the study, the participants were guided by the collectors about its objective and ethical aspects. The 
instruments were self-completed and were not necessarily answered in the presence of the collectors. The instruments consisted of self-answering questions and were not necessarily answered in the presence of the collectors (in this case, the collection was carried out by an agreed schedule between the collector and the participant in up to three attempts). All eligible participants were invited to participate in the study, 393 gave the questionnaire back.

Therefore, to compose the present study, part of the above-described database was used. Data from two questionnaires were used: the participants' biosocial and labor characterization instrument and the Safety Attitudes Questionnaire (SAQ). The participants' biosocial and labor characterization instrument was developed by the researchers and contained the following variables: sex, date of birth, marital status, number of children, work regimen, department, time of college degree and of work at the institution and department, position, level of education, weekly workload, if they have another job and workload, days without days off, if they feel satisfied with work, and intention to leave the job.

As for the $\mathrm{SAQ}$, it is an instrument for measuring the climate of safety, based on the attitudes of workers regarding patient safety. It was developed by researchers at the University of Texas ${ }^{(7)}$ and, in 2011, adapted for Brazil with an internal consistency of $0.89^{(8)}$. This instrument consists of two parts, the first with 41 items distributed in six domains (safety climate, teamwork, job satisfaction, perception of stress, working conditions, management evaluation - unit and hospital), and the second with data on the workers' profile. In the overall score, a value $\geq 75$ points is considered positive for the safety culture ${ }^{(5,7)}$.

\section{Data Analysis and Treatment}

Data were analyzed using the software PASW Statistic ${ }^{\circledR}$. To characterize the biosocial and labor profile, descriptive statistics, through absolute and relative frequency, and quantitative variables through measures of position and dispersion, according to the normal distribution of data (Kolmogorov-Smirnov test) were used. The verification of the association between the independent variables and the outcome was measured by the Chi-square, Fisher's exact, and Chi-square tests with correction. For the association of quantitative variables, the t-test or Mann-Whitney test (2 groups) was performed, according to data normality distribution. For the multivariate analysis, the Poisson Regression Model was used, applied to all associations with $\mathrm{p}$-value $<150$ for the three constructs. The significance level adopted for all tests was 5\%. The instruments internal consistency was analyzed using Cronbach's Alpha.

\section{Ethical Aspects}

The original research was approved by the Research Ethics Committee of the Universidade Federal de Santa Maria with opinion no. 2.447.277, in 2017. Ethical principles were followed according to Resolution 466/12 of the National Health Council, on research with human beings, and all participants were asked to sign the Free Informed Consent Form.

\section{RESULTS}

A total of 393 health workers participated. Of these, $58.3 \%$ work in critical areas and $41.7 \%$ in non-critical areas, with a predominance of women $(75.1 \%$ critical; $86.6 \%$ noncritical), average age of 43.4 years $( \pm 8.4)$ and 43.1 years $( \pm 8.3)$, with a partner (critical $77.5 \%$; non-critical $74.5 \%$ ) and children (critical 65.8\%; non-critical 68.3\%) (median of 2.0 children). In both areas, there was a predominance of nursing technicians (critical 43.2\%; non-critical 50.0\%), who were hired according to the Consolidated Labor Laws (CLT) regimen (critical 56.3\%; non-critical 56.4\%), worked at night (critical 31, 9\%; non-critical 36.6\%) and were satisfied with the work (critical 95.6\%; non-critical 90.9\%). There was equality for working time in the department (3.5 years), weekly working hours (36.0 hours), and number of days without days off (2.0).

As for the time of college degree in the active position, the critical areas had the highest median (12.1 years), as well as for the length of work in the institution (3.7 years). Below, Table 1 shows the results about the safety culture

Table 1 - Descriptive analysis of the Safety Attitude Questionnaire according to the perception of health workers in non-critical and critical areas. Santa Maria, Rio Grande do Sul, Brazil, 2018. $(\mathrm{n}=393)^{* *}$

\begin{tabular}{lccccccc}
\hline & \multicolumn{3}{c}{ Non-critical } & \multicolumn{3}{c}{ Critical } \\
\cline { 2 - 7 } Domains of the Safety Attitudes Questionnaire & $\mathbf{n}$ & $\overline{\mathbf{x}}$ and \pm & $\begin{array}{c}\text { Minimum and } \\
\text { maximum }\end{array}$ & $\mathbf{n}$ & $\overline{\mathbf{x}}$ and \pm & $\begin{array}{c}\text { Minimum and } \\
\text { maximum }\end{array}$ & $\mathbf{p}^{+}$ \\
\hline Total Safety Attitude Questionnaire $(\mathbf{n}=\mathbf{3 3 1})^{*}$ & 134 & $63.5(14.4)$ & $27.1-95.2$ & 197 & $66.5(12.7)$ & $30.6-96.5$ & 0.104 \\
Teamwork climate $(\mathbf{n}=\mathbf{3 7 9})^{*}$ & 158 & $68.8(17.6)$ & $16.7-100.0$ & 221 & $70.4(16.2)$ & $8.3-100.0$ & 0.328 \\
Safety climate $(\mathbf{n}=\mathbf{3 7 6})^{*}$ & 157 & $63.5(17.7)$ & $14.3-100.0$ & 219 & $67.0(16.1)$ & $21.3-100.0$ & 0.055 \\
Job satisfaction $(\mathbf{n}=\mathbf{3 8 8})^{*}$ & 161 & $80.1(17.5)$ & $25.0-100.0$ & 227 & $83.0(15.9)$ & $25.0-100.0$ & 0.114 \\
Perception of stress $(\mathbf{n}=\mathbf{3 8 0})^{*}$ & 159 & $71.2(23.8)$ & $0.0-100.0$ & 221 & $69.6(25.3)$ & $0.0-100.0$ & 0.663 \\
Perception of the unit management $(\mathbf{n}=\mathbf{3 7 8})^{*}$ & 156 & $57.1(20.1)$ & $4.2-100.0$ & 222 & $61.5(19.2)$ & $0.0-100.0$ & $\mathbf{0 . 0 4 1}$ \\
Hospital management perception $(\mathbf{n}=\mathbf{3 7 4})^{*}$ & 153 & $47.4(20.4)$ & $0.0-100.0$ & 221 & $51.0(21.5)$ & $0.0-100.0$ & 0.137 \\
Working conditions $(\mathbf{n}=\mathbf{3 8 2})^{*}$ & 161 & $59.6(24.6)$ & $8.3-100.0$ & 221 & $60.6(24.9)$ & $0.0-100.0$ & 0.573 \\
\hline
\end{tabular}

* Losses that made the individual analysis of the domain unfeasible, ** Carneiro AS, Andolhe R, Dalmolin GL, Magalhães AMM, Magnago TSBS, Arrial TS. Occupational stress, burnout and patient safety culture among workers of critical and non-critical care units in a hospital in Brazil. Nursing in critical and intensive care. 2021; 63:102978. DOI: https://doi.org/10.1016/j.iccn.2020.102978.

$\overline{\mathrm{x}}$ : mean; \pm : standard deviation; ${ }^{+}$Mann-Whitney test. 
Table 2 - Association between the Safety Attitudes Questionnaire by non-critical and critical area and biosocial variables in the work of health professionals. Santa Maria, Rio Grande do Sul, Brazil, 2018. $(\mathrm{n}=393)^{*}$

\begin{tabular}{|c|c|c|c|c|c|c|}
\hline \multirow{4}{*}{ Variable } & \multicolumn{3}{|c|}{ Non-critical } & \multicolumn{3}{|c|}{ Critical } \\
\hline & \multicolumn{6}{|c|}{ Safety culture** } \\
\hline & Negative & Positive & \multirow{2}{*}{$\mathbf{p}$} & Negative & Positive & \multirow{2}{*}{$\mathbf{p}$} \\
\hline & n (\%) & n (\%) & & n (\%) & n (\%) & \\
\hline \multicolumn{7}{|l|}{ Sex } \\
\hline Male & $18(85.7)$ & $3(14.3)$ & \multirow{2}{*}{$0.564^{r}$} & $37(72.5)$ & $14(27.5)$ & \multirow{2}{*}{$0.837^{*}$} \\
\hline Female & $87(77.7)$ & $25(22.3)$ & & $103(71.0)$ & $42(29.0)$ & \\
\hline \multicolumn{7}{|l|}{ Marital status } \\
\hline With partner & $77(80.2)$ & 19 (19.8) & \multirow{2}{*}{$0.644^{*}$} & $111(73.5)$ & $40(26.5)$ & \multirow{2}{*}{$0.281^{*}$} \\
\hline With no partner & $26(76.5)$ & $8(23.5)$ & & $28(65.1)$ & $15(34.9)$ & \\
\hline \multicolumn{7}{|l|}{ Children } \\
\hline Yes & $72(79.1)$ & $19(20.9)$ & \multirow{2}{*}{$0.942^{*}$} & $85(65.9)$ & $44(34.1)$ & \multirow{2}{*}{$0.017^{\ddagger}$} \\
\hline No & $33(78.6)$ & $9(21.4)$ & & $55(82.1)$ & $12(17.9)$ & \\
\hline \multicolumn{7}{|l|}{ Work regimen } \\
\hline CLT-hired & $59(77.6)$ & $17(22.4)$ & \multirow{3}{*}{$0.125^{\ddagger}$} & $79(69.9)$ & $34(30.1)$ & \multirow{3}{*}{$0.062 \ddagger$} \\
\hline Public officer & $41(82.0)$ & $9(18.0)$ & & $48(70.6)$ & $20(29.4)$ & \\
\hline Other & $5(83.3)$ & $1(16.7)$ & & $13(86.7)$ & $2(13.3)$ & \\
\hline \multicolumn{7}{|l|}{ Greater full training } \\
\hline Elementary/high school & $30(81.1)$ & $7(18.9)$ & \multirow{3}{*}{$0.758^{*}$} & $31(57.4)$ & $23(42.6)$ & \multirow{3}{*}{$0.023^{\ngtr}$} \\
\hline Undergraduate course & 27 (81.8) & $6(18.2)$ & & $21(72.4)$ & $8(27.6)$ & \\
\hline Graduate degree & $48(76.2)$ & $15(23.8)$ & & $88(77.9)$ & $25(22.1)$ & \\
\hline \multicolumn{7}{|l|}{ Work shift } \\
\hline Morning & $19(63.9)$ & $9(32.1)$ & \multirow{4}{*}{$0.209^{*}$} & $21(60.0)$ & $14(40.0)$ & \multirow{4}{*}{$0.389^{*}$} \\
\hline Afternoon & $22(81.5)$ & $5(18.5)$ & & $25(71.4)$ & $10(28.6)$ & \\
\hline Night & $41(87.2)$ & $6(12.8)$ & & $48(76.2)$ & $15(23.8)$ & \\
\hline Mixed & $23(74.2)$ & $8(25.8)$ & & $46(73.0)$ & $17(27.0)$ & \\
\hline \multicolumn{7}{|l|}{ Another job } \\
\hline Yes & $12(63.2)$ & $7(36.8)$ & \multirow{2}{*}{$0.124^{r}$} & $27(69.2)$ & $12(30.8)$ & \multirow[t]{2}{*}{0.734} \\
\hline No & $93(81.6)$ & $21(18.4)$ & & $113(72.0)$ & $44(28.0)$ & \\
\hline \multicolumn{7}{|c|}{ Satisfaction in working in the department } \\
\hline Yes & $90(76.3)$ & $28(23.7)$ & $0040^{r}$ & $133(71.1)$ & $54(28.9)$ & $0339^{*}$ \\
\hline No & $15(100.0)$ & $0(0.0)$ & 0.040 & $7(87.5)$ & $1(12.5)$ & 0.339 \\
\hline Intention to leave work & & & & & & \\
\hline Yes & $8(80.0)$ & $2(23.2)$ & & $16(84.2)$ & $3(15.8)$ & \\
\hline No & $76(76.8)$ & $23(23.2)$ & $0.067^{\ddagger}$ & $109(68.6)$ & $50(31.4)$ & $\mathbf{0 . 0 1 8}^{\ddagger}$ \\
\hline I don't know/I didn't think about it & $20(87.0)$ & $3(13.0)$ & & $13(86.7)$ & $2(13.3)$ & \\
\hline
\end{tabular}

* Losses. ${ }^{* *}$ Cutoff point for positive perception $\geq 75 ;{ }^{*}$ Pearson's Chi-square; ${ }^{\ddagger}$ Chi-square with correction; ' Fisher's exact.

evidenced by the SAQ, which showed excellent internal consistency (0.909).

According to Table 1, health workers from both areas have a negative perception of the safety culture $(66.5 \%, \pm 12.7$ critical; $63.5 \%, \pm 14.4$ non-critical). Only the domain job satisfaction had a positive perception $(83.0 \%, \pm 15.9$ critical; $80.1 \%, \pm 17.5$ non-critical). It is possible to notice that the critical areas obtained more positive evaluations in all domains of the SAQ when compared to the non-critical ones. There was statistical significance only for one domain, which showed a relationship between being a worker in critical areas and having a positive perception of the unit's management $(\mathrm{p}=0.041)$.

Table 2 shows the bivariate associations between patient safety culture and biosocial and labor data.

The findings in Table 2 indicate that, for workers in critical areas, there was an association between a negative perception of the safety culture and the following variables: not having children $(\mathrm{p}=0.017)$, having a graduate degree $(\mathrm{p}=0.023)$, and not knowing/not having thought about leaving the job $(p=0.018)$. For workers in non-critical areas there was an association between negative perception 
Table 3 - Correlation between patient safety culture by non-critical and critical area and biosocial and work variables of health professionals. Santa Maria, Rio Grande do Sul, Brazil, 2018. $(n=393)^{*}$

\begin{tabular}{|c|c|c|c|c|}
\hline \multirow{3}{*}{ Variables } & \multicolumn{4}{|c|}{ Safety culture } \\
\hline & \multicolumn{2}{|c|}{ Non-critical } & \multicolumn{2}{|c|}{ Critical } \\
\hline & $\mathbf{n}$ & $\mathbf{r}$ & $\mathbf{n}$ & $\mathbf{r}$ \\
\hline Age & 133 & $0.278^{* * *}$ & 194 & $0.187^{* * *}$ \\
\hline Number of children & 91 & 0.117 & 132 & -0.053 \\
\hline $\begin{array}{l}\text { Time of college degree for the } \\
\text { position }\end{array}$ & 129 & 0.092 & 194 & $0.163^{* *}$ \\
\hline $\begin{array}{l}\text { Length of work at the current } \\
\text { institution }\end{array}$ & 133 & $0.205^{* *}$ & 197 & 0.088 \\
\hline Working time in the department & 134 & 0.167 & 197 & 0.030 \\
\hline Number of days with no day off & 128 & 0.110 & 185 & -0.010 \\
\hline
\end{tabular}

* Losses. ** Significant correlation at the 0.05 level. *** Significant correlation at the 0.01 level. of patient safety and not being satisfied with work in the department $(\mathrm{p}=0.040)$.

Table 3 shows that, for critical areas, there was a low and positive correlation for age and time since graduation in the current position with the perception of safety culture. As for the non-critical areas, there was a very low and positive correlation between age and length of work at the current institution with the perception of the safety culture. Therefore, the greater the result of one, the better the result of the other.

To confirm the associations found among the variables of interest, a multivariate analysis was used using the Poisson regression model.

As for classifying the patient safety culture as negative, Table 4 indicates that workers over 43 years of age had a $22 \%$ higher prevalence than those under 42 years; those with partners, 19\% higher than those with no partners; those with a graduate degree, $21 \%$ higher than workers with

Table 4 - Gross and adjusted associations between patient safety culture and biosocial and work variables among health workers from critical and non-critical areas. Santa Maria, Rio Grande do Sul, Brazil, 2018. ( $n=393)$

\begin{tabular}{|c|c|c|c|c|c|c|}
\hline $\begin{array}{l}\text { Variables } \\
\text { Age range }\end{array}$ & $\mathbf{P R}_{\text {gross }}$ & \multicolumn{2}{|c|}{$\mathrm{Cl}(95 \%)$} & $\mathbf{P R}_{\text {adj }}$ & \multicolumn{2}{|c|}{$\mathrm{Cl}(95 \%)$} \\
\hline 43 years old or more & 1.22 & 1.058 & 1.426 & 1.22 & 1.045 & 1.446 \\
\hline Under and equal to 42 years old & 1 & - & - & 1 & - & - \\
\hline \multicolumn{7}{|l|}{ Marital status } \\
\hline With partner & 1.08 & 0.923 & 1.276 & 1.19 & 1.008 & 1.421 \\
\hline With no partner & 1 & - & - & 1 & - & - \\
\hline \multicolumn{7}{|l|}{ Training } \\
\hline Graduate degree & 1.15 & 0.978 & 1.359 & 1.21 & 1.024 & 1.444 \\
\hline Undergraduate degree & 1.15 & 0.948 & 1.407 & 1.10 & 0.900 & 1.357 \\
\hline High school & 1 & - & - & 1 & - & - \\
\hline \multicolumn{7}{|l|}{ Satisfaction in the department } \\
\hline Dissatisfied & 1.30 & 1.171 & 1.461 & 1.12 & 0.984 & 1.293 \\
\hline Satisfied & 1 & - & - & 1 & - & - \\
\hline \multicolumn{7}{|l|}{ Department } \\
\hline Non-critical & 1.10 & 0.976 & 1.252 & 1.04 & 0.921 & 1.190 \\
\hline Critical & 1 & - & - & 1 & - & - \\
\hline \multicolumn{7}{|l|}{ Another job } \\
\hline No & 1.13 & 0.933 & 1.369 & 1.15 & 0.950 & 1.391 \\
\hline Yes & 1 & - & - & 1 & - & - \\
\hline \multicolumn{7}{|l|}{ Intention to leave work } \\
\hline Do not know & 1.21 & 1.047 & 1.401 & 1.19 & 1.037 & 1.378 \\
\hline Yes & 1.15 & 0.961 & 1.386 & 1.10 & 0.910 & 1.352 \\
\hline No & 1 & - & - & 1 & - & - \\
\hline \multicolumn{7}{|l|}{ Work regimen } \\
\hline Other & 1.17 & 0.966 & 1.427 & 1.07 & 0.848 & 1.352 \\
\hline Public officer & 1.03 & 0.903 & 1.182 & 1.10 & 0.945 & 1.281 \\
\hline CLT-hired & 1 & - & - & 1 & - & - \\
\hline
\end{tabular}

Notes: PR: Prevalence ratio (gross and adjusted). Cl: Confidence Interval. Dependent variable: Safety culture (Safety Attitudes Questionnaire).

Adjusted model: safety culture, age, marital status, education, satisfaction with the department, work department, other job, intention to leave the job, and work regimen. 
secondary/elementary education or undergraduate degree; those who do not know if they want to leave their job had a 19\% higher prevalence when compared to those who do not want to leave their job.

\section{DISCUSSION}

The negative perception of the patient safety culture found in this study was also evidenced in national and international investigations ${ }^{(9-15)}$, as well as the positive evaluation only for the job satisfaction domain ${ }^{(16-17)}$. Job satisfaction is understood as the sum of favorable feelings that workers have in relation to it, and the greater the satisfaction, the greater the worker's effort to qualify care ${ }^{(18)}$. A study indicated that job satisfaction was related to remuneration, workload, teamwork, recognition of work, autonomy, and resolvability in care, and the fact of working in a public institution. Moreover, the authors emphasize that the identification of these factors can contribute to the maintenance or maximization of satisfaction, aiming at improving the quality of life at work and the quality of care ${ }^{(19)}$.

On the other hand, the domain with the lowest score was the perception of hospital management, similar to other investigations ${ }^{(20-21)}$. This indicates that there is a gap between workers and managers, a fact that can hinder workers' participation in administrative decisions, which results in demotivation at work and affects the increase in adverse events $^{(22-23)}$.

The institution's management is primarily responsible for planning, developing, and monitoring actions and strategies of the organizational culture aimed at promoting safety and, therefore, shall be able to sensitize workers in favor of these measures ${ }^{(20)}$. Studies show that the lack of management flexibility as responsible for the punitive culture of errors is capable of causing greater damage, because the punitive character oppresses and frightens workers, resulting in low error notification rates ${ }^{(24-25)}$. To improve this situation, it is urgent to inform, organize, and articulate institutional mechanisms, where the presence of an adequate leadership is seen as an aspect capable of driving changes, aiming at the adoption of safe practices ${ }^{(26)}$.

A Danish study shows that, after training, strengthening leadership acted as a catalyst both for improvements in health workers' teams with positive attitudes and for the culture of patient safety. Thus, for hospitals to reach levels of excellence, it is important that the leader has knowledge, skill, and competence to facilitate communication, ability to resolve conflicts, create motivation, promote development and improvement through actions aiming at building and strengthening a safe environment ${ }^{(27)}$.

In addition, there was an association between being a worker in critical areas and having a positive perception in relation to the unit's management, indicating a greater approach and performance of the management team in these spaces. Working conditions, such as supervision, communication, equipment, knowledge, and skills, are important factors in assessing the perception of patient safety culture. Added to this, there are the characteristics of workers and patients, which are also determinants of clinical practice variability. Thus, workers from critical areas tend to have more control over these conditions, as they work under more rigid realities and with high surveillance, given these environments complexity ${ }^{(28)}$.

Furthermore, critical areas scored slightly more positively across all domains of SAQ. This result shows that these health workers assess the patient safety culture in their work environments in a better way. There is an overall trend towards more positive scores for the SAQ when applied in these areas. Therefore, it is possible to infer that this result is directly linked to the different characteristics of the work process in critical areas. Despite this, there was no statistically significant difference in the general perception of safety culture among the areas.

In the bivariate associations, several significant associations were found. However, when placed in the multivariate analysis model to neutralize possible confounding factors, only the following variables remained in fact significant compared to the negative evaluation of the patient safety culture: being over 43 years old, having partners, having a graduate degree, and not knowing if they want to quit the job.

In addition, being over 43 years of age also proved to be a factor that increased the chances of negatively evaluating the patient safety culture, as age is often accompanied by longer professional experience, as well as working in a particular institution or unit ${ }^{(29)}$. This fact can lead to different perceptions of reality when compared to younger workers, since the experience lived throughout life can make the worker more reflective and critical regarding work environment conditions.

The fact of having a partner being associated with a negative safety culture may be related to the women performing different social roles, as this sex was predominant in this study. The activities of domestic, family, and social life, combined with work, can represent stressors, resulting in a negative evaluation of the patient safety culture. Furthermore, as the predominance of night service or mixed service was present in this investigation, it is possible that this condition makes it difficult to manage activities in the world of work with personal and social life.

Moreover, having a graduate degree was also a factor associated with a negative safety culture. A link that can be made as professionals who undertake graduate studies are expected to be more encouraged to exercise critical and reflective thinking, and, therefore, have better conditions to assess the work environment according to realistic perspectives ${ }^{(30)}$.

Finally, indecision about leaving the job was also significantly associated with a negative evaluation of the patient safety culture. This indecision may be linked to the mismatch between the occupational trajectory and expectations of professional fulfillment. However, evidence indicates that the difficulties and uncertainties experienced in the beginning of professional life are attenuated, but do not disappear completely ${ }^{(30)}$. Thus, it is possible to infer that workers who are indecisive about their professional performance tend to be dissatisfied or frustrated with it, a fact that leads them to 
negatively evaluate aspects related to the work environment in which they are inserted.

It is worth noting that the investigation has some limitations, such as the population's adherence to the study, considering that the original research was a census. There was also some difficulty in discussing the findings related to non-critical areas, as most of the published studies refer to critical areas, making the comparison of results difficult. It should be noted that it is not possible to generalize the data, as they refer to a specific population in a specific geographic region of the country.

As for the contributions to the construction of knowledge in health, the original character of the study stands out, as it elucidates comparative questions about the patient safety culture in critical and non-critical areas. This is because the differences in the work process of the critical areas were not sufficient for their workers to positively evaluate the patient safety culture in the institution studied. This justifies that both areas need actions to promote and strengthen the safety culture. Furthermore, it is possible that, in the reality studied, the characteristics of patients with complex clinical conditions make non-critical units increasingly demanding of qualified human and material resources.

\section{CONCLUSION}

The SAQ analysis showed that health workers from critical and non-critical areas have a negative perception of the patient safety culture. Although, in general, the critical areas obtained more positive evaluations in all domains of the SAQ, the result of the general score was not statistically significant when compared to the non-critical areas. Therefore, the findings denied the study's initial hypothesis that there is a difference between the patient safety culture in critical and non-critical areas in the hospital environment.

\section{RESUMO}

Objetivo: comparar a percepção da cultura de segurança do paciente entre trabalhadores de saúde de áreas críticas e não críticas. Método: estudo transversal com trabalhadores de saúde das áreas críticas e não críticas de um hospital de grande porte. A coleta de dados utilizou instrumento de caracterização e o Safety Attitudes Questionnaire. A análise ocorreu no Predictive Analytics Software Statistic ${ }^{\circledR}$. Resultados: participaram 393 trabalhadores, predominantemente mulheres, acima de 43 anos, técnicas de enfermagem, com companheiro e filhos. Resultados indicaram que as áreas têm percepção negativa da segurança do paciente $(66,5 \%, \pm 12,7$ críticas; $63,5 \%, \pm 14,4$ não críticas). Somente a satisfação no trabalho obteve escore positivo $(83,0 \%, \pm 15,9$ críticas; $80,1 \%, \pm 17,5$ não críticas). Houve relação entre ser trabalhador de áreas críticas e ter percepção positiva para gerência da unidade $(p=0,041)$. Conclusão: ambas as áreas têm percepção negativa da cultura de segurança. Embora áreas críticas tenham obtido avaliações mais positivas, os resultados não apresentaram significância estatística quando comparados às áreas não críticas.

\section{DESCRITORES}

Enfermagem; Segurança do paciente; Hospitais; Unidades hospitalares; Estudo comparativo.

\section{RESUMEN}

Objetivo: comparar la percepción de la cultura de seguridad del paciente entre trabajadores de salud de áreas críticas y no críticas. Método: estudio transversal con trabajadores de salud de las áreas críticas y no críticas de un hospital de gran porte. La recolección de datos utilizó instrumento de caracterización y el Safety Attitudes Questionnaire. El análisis ocurrió en el Predictive Analytics Software Statistic ${ }^{\circledR}$. Resultados: participaron 393 trabajadores, entre los cuales predominaron mujeres, con más de 43 años, técnicas de enfermería, casadas y con hijos. Resultados indicaron que las áreas han tenido percepción negativa de la seguridad del paciente $(66,5 \%, \pm 12,7$ críticas; $63,5 \%, \pm 14,4$ no críticas). Solamente la satisfacción en el trabajo obtuvo score positivo $(83,0 \%, \pm 15,9$ críticas; $80,1 \%, \pm 17,5$ no críticas). Hubo relación entre el hecho de ser trabajador de áreas críticas y haber tenido percepción positiva para gerencia de la unidad ( $\mathrm{p}=0,041)$. Conclusión: las dos áreas poseen percepción negativa de la cultura de seguridad. Aunque áreas críticas obtuvieron evaluaciones más positivas, los resultados no presentaron significancia estadística cuando comparados a las áreas no críticas.

\section{DESCRIPTORES}

Enfermería; Seguridad del Paciente; Hospitales; Unidades Hospitalarias; Estudio Comparativo.

\section{REFERENCES}

1. Brasil. Ministério da Saúde. Agência Nacional de Vigilância Sanitária. Resolução - RDC no 36, de 25 de julho de 2013 . Institui ações para a segurança do paciente em serviços de saúde e dá outras providências [Internet]. Brasília; 2013 [cited 2021 Jun 03]. Available from: http://bvsms.saude.gov.br/bvs/saudelegis/anvisa/2013/rdc0036_25_07_2013.html.

2. Reis GAX, Oliveira JLC, Ferreira AMD, Vituri DW, Marcon SS, Matsuda LM. Difficulties to implement patient safety strategies: perspectives of management nurses. Rev Gaucha Enferm. 2019;40(esp):e20180366. DOI: https://doi.org/10.1590/1983-1447.2019.20180366.

3. Zottele C, Magnago TSBS, Dullius AIS, Kolankiewicz ACB, Ongaro JD. Hand hygiene compliance of healthcare professionals in an emergency department. Rev Esc Enferm USP. 2017;51:e03242. DOI: https://doi.org/10.1590/S1980-220X2016027303242.

4. Carneiro AS, Andolhe R, Lanes TC, Magnago TSBS. Patient safety culture in hospital environment: trends in brazilian production. Research, Society and Development. 2020;9(7):e963975132. DOI: http://dx.doi.org/10.33448/rsd-v9i7.5132.

5. Sexton JB, Thomas EJ, Grillo SP. The Safety Attitudes Questionnaire: Guidelines for administration. 2/03. Texas: University of Texas; 2003. $194 \mathrm{p}$.

6. Hill MM, Hill A. Investigação por questionário. Lisboa: Editora Sílado; 2002.

7. Sexton JB, Helmreich RL, Neilands TB, Rowan K, Vella K, Boyden J, et al. The Safety Attitudes Questionnaire: psychometric properties, benchmarking data, and emerging research. BMC Health Serv Res. 2006;6(44):1-10. DOI: https://doi.org/10.1186/1472-6963-6-44. 
8. Carvalho REFL, Cassiani SHB. Cross-cultural adaptation of the Safety Attitudes Questionnaire - Short Form 2006 for Brazil. Rev Lat Am Enfermagem. 2012;20(3):575-82. DOI: https://doi.org/10.1590/S0104-11692012000300020.

9. Salles MM, Ferreira DSS, Lôbo IMF. Culture of security: perception of nursing professionals of a teaching hospital. Brazilian Journal of health Review [Internet]. 2019 [cited 2020 Apr 5];2(2):1213-9. Available from: http://www.brazilianjournals.com/index.php/BJHR/article/ view/1331.

10. Zanon REB, Dalmolin GL, Magnago TSBS, Andolhe R, Carvalho REFL. Presenteeism and safety culture: evaluation of health workers in a teaching hospital. Rev Bras Enferm. 2021;74(1):e20190463. DOI: http://dx.doi.org/10.1590/0034-7167-2019-0463.

11. Carvalho REFL, Arruda LP, Nascimento NKP, Sampaio RL, Cavalcante MLSN, Costa ACP. Assessment of the culture of safety in public hospitals in Brazil. Rev Lat Am Enfermagem. 2017;25:e2849. DOI: https://doi.org/10.1590/1518-8345.1600.2849.

12. Göras C, Unbeck M, Nilsson U, Ehrenberg A. Interprofessional team evaluations of the patient safety climate in Swedish operating rooms: a cross-sectional survey. BMJ Open. 2017:7(e015607). DOI: http://dx.doi.org/10.1136/bmjopen-2016-015607.

13. Klemenc-Ketis Z, Deilkås ET, Hofoss D, Bondevik GT. Variations in patient safety climate and perceived quality of collaboration between professions in out-of-hours care. J Multidiscip Healthc. 2017;10:417-23. DOI: https://doi.org/10.2147/JMDH.S149011.

14. Thomas A, Lomas JP. Establishing the use of a safety attitudes questionnaire to assess the safety climate across a critical care network. J Intensive Care Soc. 2018;19(3):219-25. DOI: https://doi.org/10.1177/1751143717750788.

15. Gleeson LL, Tobin L, O'Brien GL, Crowley EK, Delaney A, O'Mahony, D, et al. Safety culture in a major accredited Irish university teaching hospital: a mixed methods study using the safety attitudes questionnaire. Ir J Med Sci. 2020;189(4):1171-8. DOI: https://doi.org/10.1007/ s11845-020-02228-0.

16. Golle L, Ciotti D, Herr GEG, Aozane F, Schmidt CR, Kolankiewicz ACB. Culture of patient safety in hospital private. Revista de pesquisa, cuidado é fundamental online. 2018;10(1):85-9. DOI: https://doi.org/10.9789/2175-5361.2018.v10i1.85-89.

17. Toso GL, Golle L, Magnago TSBS, Herr GEG, Loro MM, Aozane F, et al. Patient safety culture in hospitals within the nursing perspective. Rev Gaucha Enferm. 2016;37(4):e58662. DOI: https://doi.org/10.1590/1983-1447.2016.04.58662.

18. Morais MP, Martins JT, Galdino MJQ, Robazzi MLCC, Trevisan GS. Nurses's work satisfaction in a university hospital. Revista de Enfermagem da UFSM. 2016;6(1):1-9. DOI: https://doi.org/10.5902/2179769217766.

19. Magalhães FHL, Pereira ICA, Luiz RB, Barbosa MH, Ferreira MBG. Patient safety atmosphere in a teaching hospital. Rev Gaucha Enferm. 2019;40(esp):e20180272. DOI: https://doi.org/10.1590/1983-1447.2019.20180272.

20. Santos FJ, Nascimento HM, Santos JMJ, Cunha JO, Santos JCS, Pena JA. Patient safety culture in a low-risk maternity hospital. ABCS health sciences. 2019;44(1):52-7. DOI: https://doi.org/10.7322/abcshs.v44i1.1066.

21. Christoff A, Duns N. P0527 / \#484: Leading a culture of safety in the picu utilizing the safety attitudes questionnaire. Pediatric Critical Care Medicine. 2021;22(Suppl 1 3S):265. DOl: https://doi.org/10.1097/01.pcc.0000740448.79742.7b.

22. Sousa P, Mendes W, organizadores. Segurança do paciente: conhecendo os riscos nas organizações de saúde [Internet]. $2^{\mathrm{a}}$ ed. Rio de Janeiro: Fiocruz; 2019 [cited 2020 Apr 05]. Available from: http://books.scielo.org/id/tzvzr/pdf/sousa-9788575416419.pdf.

23. Minuzzi AP, Salum NC, Locks MOH. Assessment of patient safety culture in intensive care from the health team's perspective. Texto \& contexto enferm. 2016;25(2):e1610015. DOI: https://doi.org/10.1590/0104-07072016001610015.

24. Viana de Lima Neto A, Silva MF, Medeiros SG, Barbosa ML, Salvado PTCO, Santos VEP. Patient Safety Culture in Health Organizations: Scoping Review. Int Arch Med. 2017;10(74):1-13. DOI: https://doi.org/10.3823/2344.

25. Rocha NHG, Oliveira KF, Nascimento KG, Cordeiro ALPC, Haas VJ, Oliveira JF, et al. Socio-demographic and professional determinants in patient safety culture. Revista de Enfermagem e Atenção à Saúde. 2017;6(1):80-94. DOI: https://doi.org/10.18554/reas.v6i1.2025.

26. Kristensen S, Christensen KB, Jaquet A, Beck CM, Sabroe $S$, Bartels $P$, et al. Strengthening leadership as a catalyst for enhanced patient safety culture: a repeated cross-sectional experimental study. BMJ Open. 2016;6(5)e010180. DOI: https://doi.org/10.1136/bmjopen-2015-010180.

27. Santiago THR, Turrini RMT. Organizational culture and climate for patient safety in Intensive Care Units. Rev Esc Enferm USP. 2015:49(spe):123-30. DOI: https://doi.org/10.1590/S0080-623420150000700018.

28. Almeida LA, Medeiros IDS, Barros AG, Martins CCF, Santos VEP. Generating factors of Burnout Syndrome in health professionals. Revista de pesquisa, cuidado é fundamental online. 2016;8(3):4623-8. DOI: https://doi.org/10.9789/2175-5361.2016.v8i3.4623-4628.

29. Falkenberg MB, Mendes TPL, Moraes EP, Souza EM. Health education and education in the health system: concepts and implications for public health. Cien Saude Colet. 2014;19(3):847-52. DOI: https://doi.org/10.1590/1413-81232014193.01572013.

30. Vieira M, Chinelli F, D'Ávila LS, Fortes DR, David NAS. Educational and occupational trajectories of workers of the Unified Health System and their professional expectations. Saúde debate. 2017;41(spe2):92-103. DOI: https://doi.org/10.1590/0103-11042017s208. 